\title{
Idaho National Engineering and Environmental Laboratory Offsite Environmental Surveillance Program Report: Fourth Quarter 1998
}

\author{
Troy Saffle \\ Roy Evans
}

Environmental Science and Research Foundation, Inc. Doyle Markham, Executive Director

August 1999

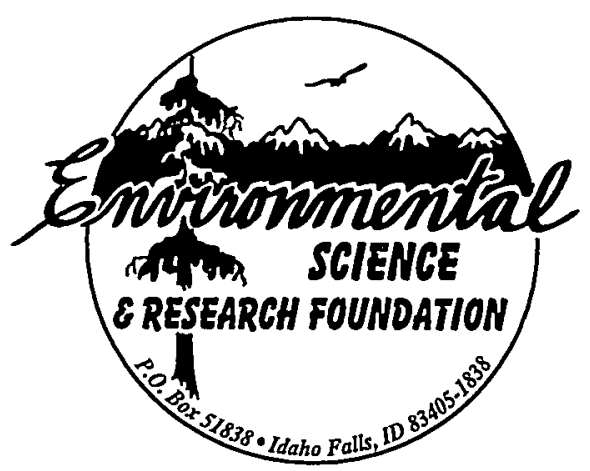

Program conducted for the U.S. Department of Energy, Idaho Operations Office Under Contract DE-AC07-94ID13268 Environmental Science and Research Foundation, Inc. 101 S. Park Avenue, Suite 2

P.O. Box 51838

Idaho Falls, Idaho $83405-1838$ 


\section{DISCLAIMER}

This report was prepared as an account of work sponsored by an agency of the United States Government. Neither the United States Government nor any agency thereof, nor any of their employees, make any warranty, express or implied, or assumes any legal liability or responsibility for the accuracy, completeness, or usefulness of any information, apparatus, product, or process disclosed, or represents that its use would not infringe privately owned rights. Reference herein to any specific commercial product, process, or service by trade name, trademark, manufacturer, or otherwise does not necessarily constitute or imply its endorsement, recommendation, or favoring by the United States Government or any agency thereof. The views and opinions of authors expressed herein do not necessarily state or reflect those of the United States Government or any agency thereof. 


\section{DISCLAIMER}

Portions of this document may be illegible in electronic image products. Images are produced from the best available original document. 


\section{Executive Summary}

The Environmental Science and Research Foundation conducts the Offsite Environmental Surveillance Program at the U.S. Department of Energy's Idaho National Engineering and Environmental Laboratory (INEEL). The Foundation's environmental surveillance program monitors the effects, if any, of U.S. Department of Energy (DOE) activities on the offsite environment, collects data to confirm compliance with applicable environmental laws and regulations, and observes any trends in environmental levels of radioactivity. This report for the fourth quarter 1998 is based on 622 samples collected of air, fine particulates, atmospheric moisture, precipitation, water, milk, potatoes, and game animals. All concentrations of radioactivity found in these samples were consistent with concentrations which have been found in sampling during recent quarters and which have been attributed in the past to natural background radioactivity, worldwide fallout from past nuclear weapons testing, and nuclear operations around the world. No measured concentrations could be directly attributed to operations at the INEEL, although statistical differences did exist between on-site and distant gross beta concentrations. No evidence could be found to link these differences with a specific INEEL source. Concentrations in all samples were below the guidelines set by both the DOE and the U.S. Environmental Protection Agency (EPA) for protection of the public.

\section{Program Description}

The Foundation collected filters weekly from low-volume air samplers at 12 offsite locations. Five were at distant locations and seven were near the INEEL boundary. An additional three air samplers were operated on the INEEL. Replicate samplers were operated at two offsite boundary locations for quality assurance purposes. Weekly measurements were made of gross alpha and gross beta activity in airborne particulates. Charcoal cartridges were screened weekly for the presence of iodine-131. At the end of the quarter, weekly filters from each location were combined to form a composite sample for that location. These composites were then analyzed for gamma-emitting radionuclides. Selected composites were also submitted for analyses for strontium-90 and transuranics (plutonium-238, plutonium-239/240, and americium-241).

$\mathrm{PM}_{10}$ samplers were operated at three offsite locations to sample airborne particulates with an aerodynamic diameter smaller than 10 microns. Particles this size can penetrate the body's natural air filtering system and enter the lungs.

Atmospheric moisture and precipitation samples were collected to monitor for tritium. Atmospheric moisture samples were collected by sampling continuously for 13 weeks at each of four locations. The Foundation collected monthly precipitation samples at one onsite location and one offsite location, as well as a weekly precipitation sample at a second onsite location.

Water samples were collected in November from 14 drinking water locations and four surface water locations in the Magic valley and in Idaho Falls. Gross alpha and gross beta activities and tritium concentrations were determined for all samples.

The Foundation collected a weekly milk sample from a dairy in Idaho Falls and collected monthly milk samples from eight additional dairies around the INEEL. All milk samples were analyzed for iodine-131. Selected samples were analyzed for strontium- 90 .

Potatoes were collected from area farms surrounding the INEEL and tested for gammaemitting radionuclides. Selected samples were analyzed for strontium-90. 
Seven big game animals were killed accidentally on INEEL roads during the quarter, and tissue samples of muscle, thyroid, and liver were collected from each of these animals and subjected to gamma spectroscopic analysis.

The Foundation collected 14 offsite TLDs (thermoluminescent dosimeters) to determine environmental radiation levels around the INEEL.

For more information concerning the contents of this report, contact the Foundation at (208) 525-7102, or visit the Foundation's web page (http://esrf.org).

\section{Summary of Fourth Quarter 1998 Results}

During the fourth quarter of 1998, gross alpha and gross beta activities in low-volume air samples were within the expected range of values for background radioactivity. Although the quarterly mean of gross beta activities in air observed at stations on the INEEL was higher than that observed at distant stations, the difference between INEEL stations and boundary staions was not significant. No statistically significant differences were observed in the quarterly mean of gross alpha activities measured at INEEL stations as compared with those distant and boundary stations. Iodine-131 was not found in any air sample. No specific radionuclide was detected in selected composite samples with either gamma spectroscopy or radiochemical analyses. The higher gross beta concentrations on the INEEL were probably attributable to normal fluctuations in concentrations of naturally-occurring radionuclides rather than to INEEL operations.

$\mathrm{PM}_{10}$ sampling for respirable particulates continued in three locations: Atomic City, Rexburg, and Mountain View Middle School in Blackfoot. Twenty-four-hour samples were collected once every six days throughout the fourth quarter. Observed concentrations at the three stations were all below the short-term EPA standard of $150 \mu \mathrm{g} / \mathrm{m}^{3}$ averaged over 24 hours.

Tritium was detected in one atmospheric moisture sample and in one weekly precipitation sample. However, tritium was not detected in any of the surface or drinking water samples. The observed tritium concentrations in precipitation samples were well below DOE derived guidelines for the general public and can probably be attributed to cosmic ray bombardment of the atmosphere.

Gross alpha activity was detected in one of the water samples taken from the Magic Valley. All of the samples contained detectable gross beta activity, consistent with levels measured previously and probably attributable to natural radioactivity.

No detectable concentrations of iodine- 131 were reported in the 38 milk samples collected during the fourth quarter. A low concentration of strontium- 90 was detected in a milk sample from Dietrich. Of seven potato samples collected and analyzed during the fourth quarter, three contained low concentrations of strontium-90. Of two elk and five mule deer killed accidentally on NEEL roads during the quarter, muscle samples from one elk and four deer exhibited low but detectable concentrations of cesium-137, and a liver sample from one deer also contained a detectable concentration of cesium-137. All of these concentrations were in the range of concentrations which have been observed in similar samples in the past and which can probably be attributed to worldwide fallout from above-ground nuclear weapons testing.

TLD measurements were comparable to data from past years and exhibited no statistically significant difference between distant and boundary locations. 


\section{Table of Contents}

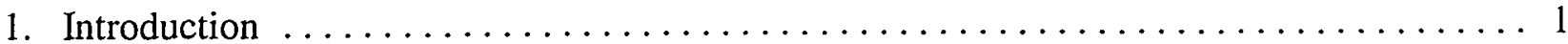

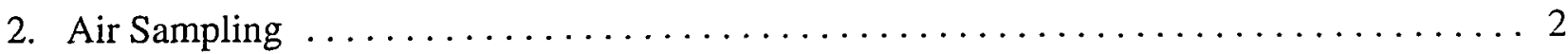

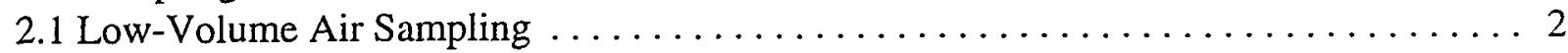

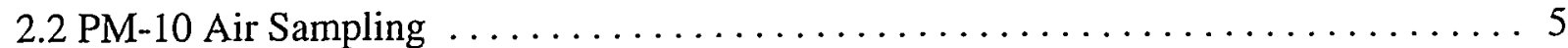

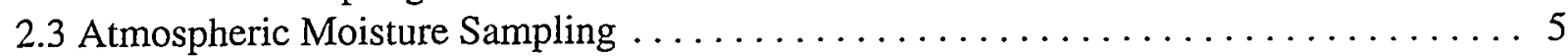

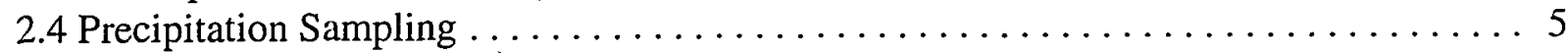

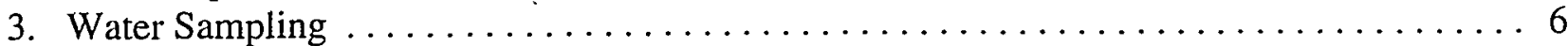

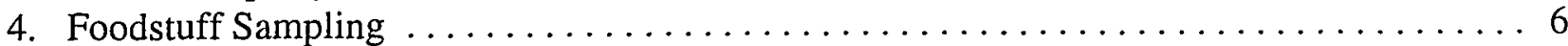

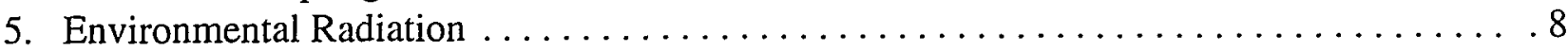

Appendix A: Summary of Environmental Surveillance Networks . . . . . . . . . . . 9

Appendix B: Helpful Information for Readers $\ldots \ldots \ldots \ldots \ldots \ldots \ldots \ldots \ldots \ldots \ldots \ldots \ldots$

Appendix C: Weekly Gross Alpha and Beta Activities in Air $\ldots \ldots \ldots \ldots \ldots \ldots \ldots$

\section{Tables}

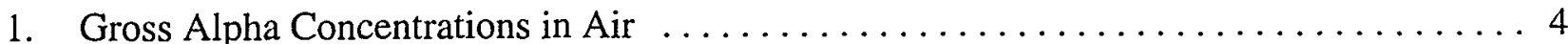

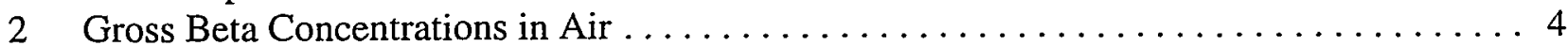

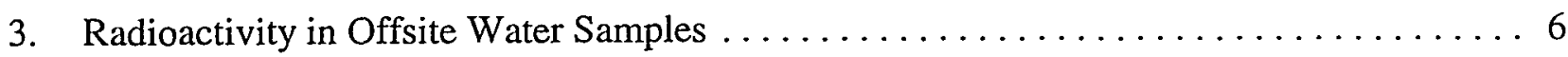

4. Cesium-137 Concentrations in Wild Game ......................... 7

5. Radiation Exposures at Distant and Boundary Locations (1998) ............... 8

Figures

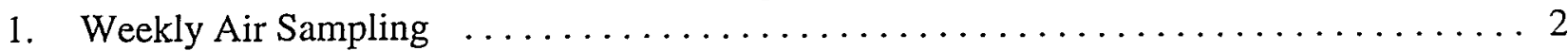

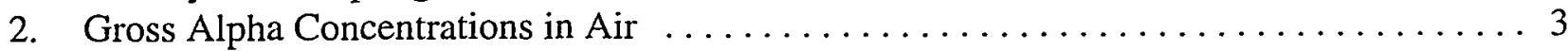

3. Gross Beta Concentrations in Air ................................. 3

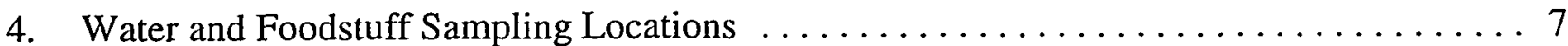

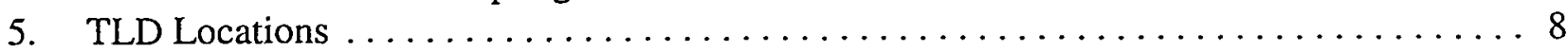




\section{Introduction}

This quarterly report summarizes data collected by the Foundation's Idaho National Engineering and Environmental Laboratory (INEEL) Offsite Environmental Surveillance Program during the period October 7 to December 30,1998. Consistent with requirements of applicable Department of Energy (DOE) Orders, the Foundation's environmental surveillance program monitors the effects, if any, of DOE activities on the offsite environment, collects data to verify compliance with applicable environmental laws and regulations, and observes trends in environmental levels of radioactivity. Appendix A summarizes the Foundation's surveillance program. Information useful in understanding this report is given in Appendix B.

Most of the reported environmental concentrations are at or near background levels of radioactivity; many results are near the detection limits of the laboratory procedures. Appendix A summarizes the approximate minimum detectable concentrations of radioactivity which can be detected and quantified for a given sample type and analysis. All results are reported with an associated 2s ("two sigma") uncertainty term. The Foundation uses the following method for interpreting analytical results near the minimum detectable concentration: results less than or equal to the $2 \mathrm{~s}$ uncertainty, which includes some negative values, are considered as "not detected." For results greater than $2 \mathrm{~s}$ (the $95 \%$ confidence level), but not exceeding $3 \mathrm{~s}$ (the $99 \%$ confidence interval), detection of the radioactivity is questionable. Results may exceed the $2 \mathrm{~s}$ level simply due to the inherent random nature of radioactive decay events. This is expected to occur approximately $2.5 \%$ of the time. Results exceeding $3 \mathrm{~s}$ are interpreted as indicating the detection of radioactivity.

Where appropriate, the results in this report are compared to the following:

- For air, concentrations are compared to the DOE Derived Concentration Guides. The Derived Concentration Guide is the concentration of a radionuclide which, under conditions of continuous exposure for a year, would result in an effective dose equivalent of 100 mrem (the DOE standard for members of the public);

- For drinking water, concentrations are compared to the Environmental Protection Agency's Maximum Contaminant Level. This is the maximum permissible level of a contaminant in water which is delivered to any user of a community water system. 


\section{Air Sampling}

\subsection{Low-Volume Air Sampling}

Airborne particulate radioactivity was continuously monitored by 17 air samplers (Figure 1), located to provide an effective network to detect INEEL releases of radioactivity. Five offsite air samplers are designated as distant, or background, stations and seven are designated as boundary stations. Three air samplers are situated on the INEEL. Two replicate samplers are also

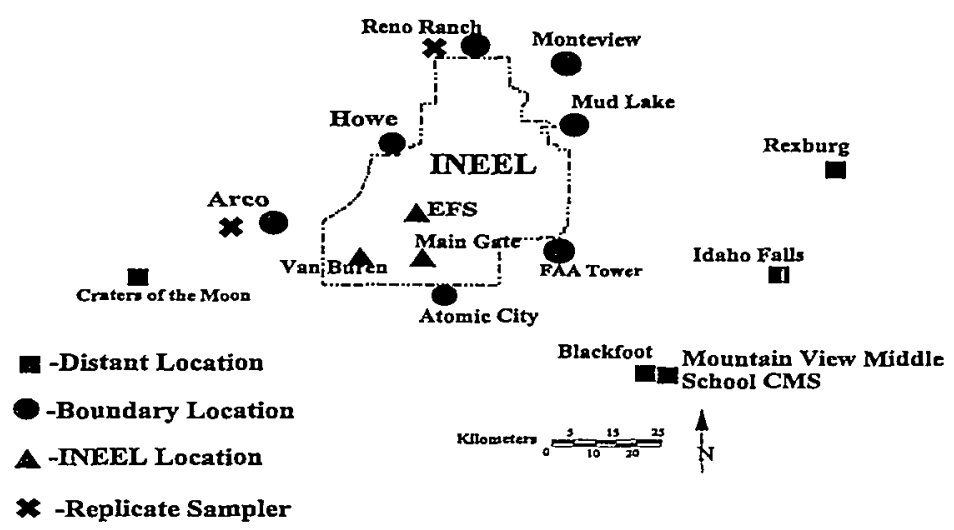

Figure 1 Weekly Air Sampling operated for quality control purposes. Distant locations were used to make comparisons of airborne concentrations of radioactivity with boundary and onsite locations. Each air sampler averaged a flow of approximately $50 \mathrm{l} / \mathrm{min}\left(2 \mathrm{ft}^{3} / \mathrm{min}\right)$ through a filter head consisting of two types of filters-a 1.2-micrometer pore size particulate filter and a charcoal cartridge for the monitoring of radioactive iodine. Filters on each sampler were changed weekly.

Various screening analyses were performed weekly. Charcoal cartridges were screened weekly in batches for ${ }^{131} \mathrm{I}$ activity. If activity was detected in any batch greater than a preset action level, cartridges were then analyzed individually. Particulate filters were counted each week for gross (nonspecific) beta activity in a low-background beta counter after waiting a minimum of four days for the naturally occurring daughter products of radon and thoron decay. The particulate filters were also counted for gross alpha activity. At the end of the quarter, weekly filters from each location were combined to form a composite. All composites were then analyzed by gamma spectrometry for specific radionuclides. Selected composites were also analyzed for ${ }^{90} \mathrm{Sr}$ or transuranic radionuclides $\left({ }^{238} \mathrm{Pu},{ }^{239 / 240} \mathrm{Pu}\right.$, and $\left.{ }^{241} \mathrm{Am}\right)$.

No ${ }^{131} \mathrm{I}$ was detected in any of the weekly charcoal cartridges during the fourth quarter.

Figure 2 shows the weekly gross alpha activities measured throughout the quarter. All measured gross alpha activities were within the expected range of background levels and were generally lower at the INEEL than at boundary or distant stations. Table 1 summarizes the gross alpha measurements for the quarter. There were no statistically significant differences between the quarterly mean of the gross alpha activities observed at stations on the INEEL and the means observed at distant and boundary stations. 
Figure 3 shows gross beta activities over the 13-week quarter. All measured beta activities were also within the range of expected background values. At the $95 \%$ confidence interval, the mean of the weekly gross beta activities observed at stations on the INEEL was significantly higher than that of the distant stations. However, there was no statistically significant difference between the mean of weekly gross beta activities observed at stations on the INEEL and that of the boundary stations. No man-made radionuclides were detected either by gamma spectroscopic analyses of the quarterly composite

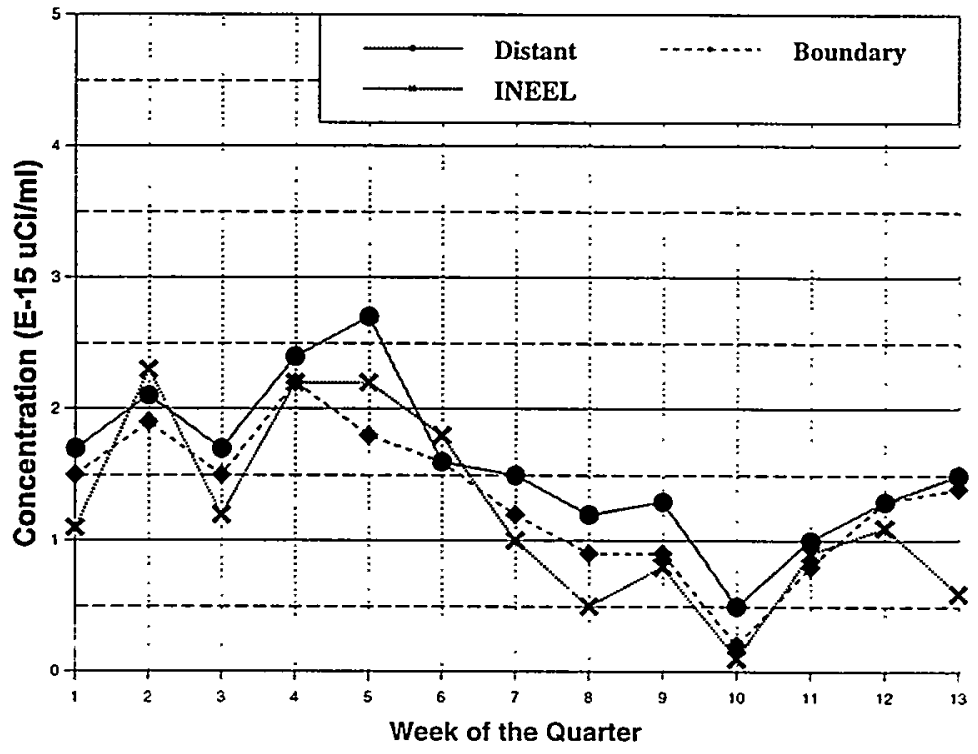

Figure 2 Gross Alpha Activity in Air samples or by radiochemical analyses of selected composites for ${ }^{90} \mathrm{Sr},{ }^{241} \mathrm{Am},{ }^{238} \mathrm{Pu}$, and ${ }^{239 / 240} \mathrm{Pu}$. The difference between INEEL and distant stations in mean gross beta concentrations is therefore unlikely to be attributable to INEEL operations and is probably due to normal fluctuations in concentrations of naturally-occurring radionuclides.

Replicate low-volume samplers were operated at Arco and at Reno Ranch for quality assurance purposes. There were no statistically significant differences between the mean values for gross alpha and gross beta at each of these sites and the means of their respective replicates. Appendix $\mathrm{C}$ contains the observed values of gross alpha and gross beta activities found in weekly air samples.

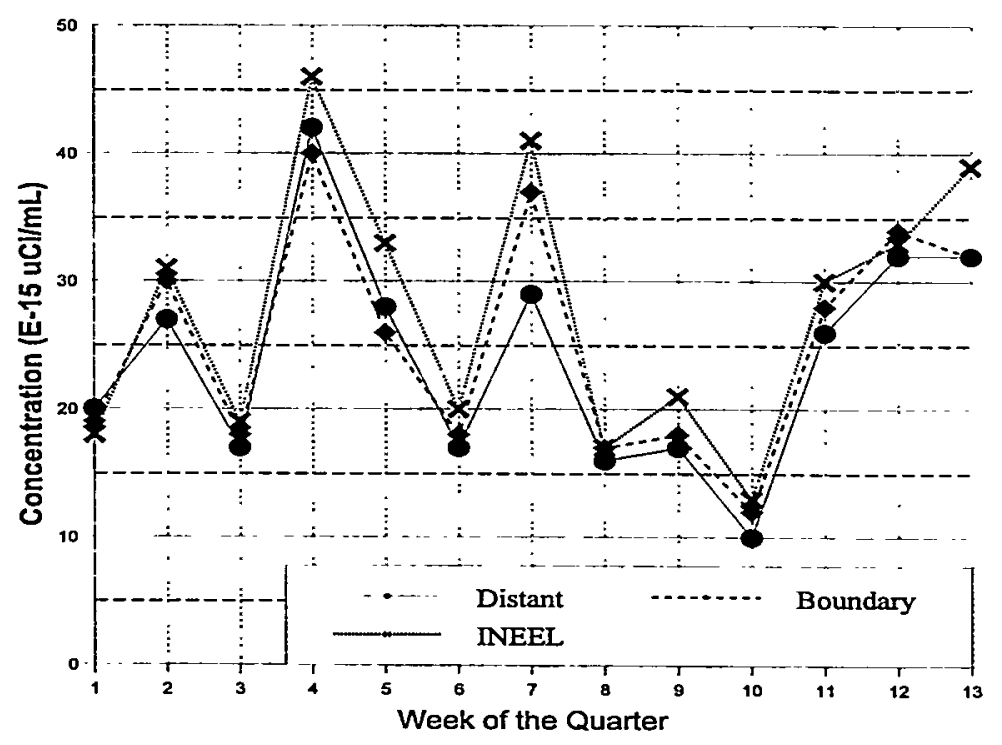

Figure 3 Gross Beta Activity in Air 


\section{Air Sampling}

Table 1

Gross Alpha Concentrations in Air

Fourth Quarter 1998

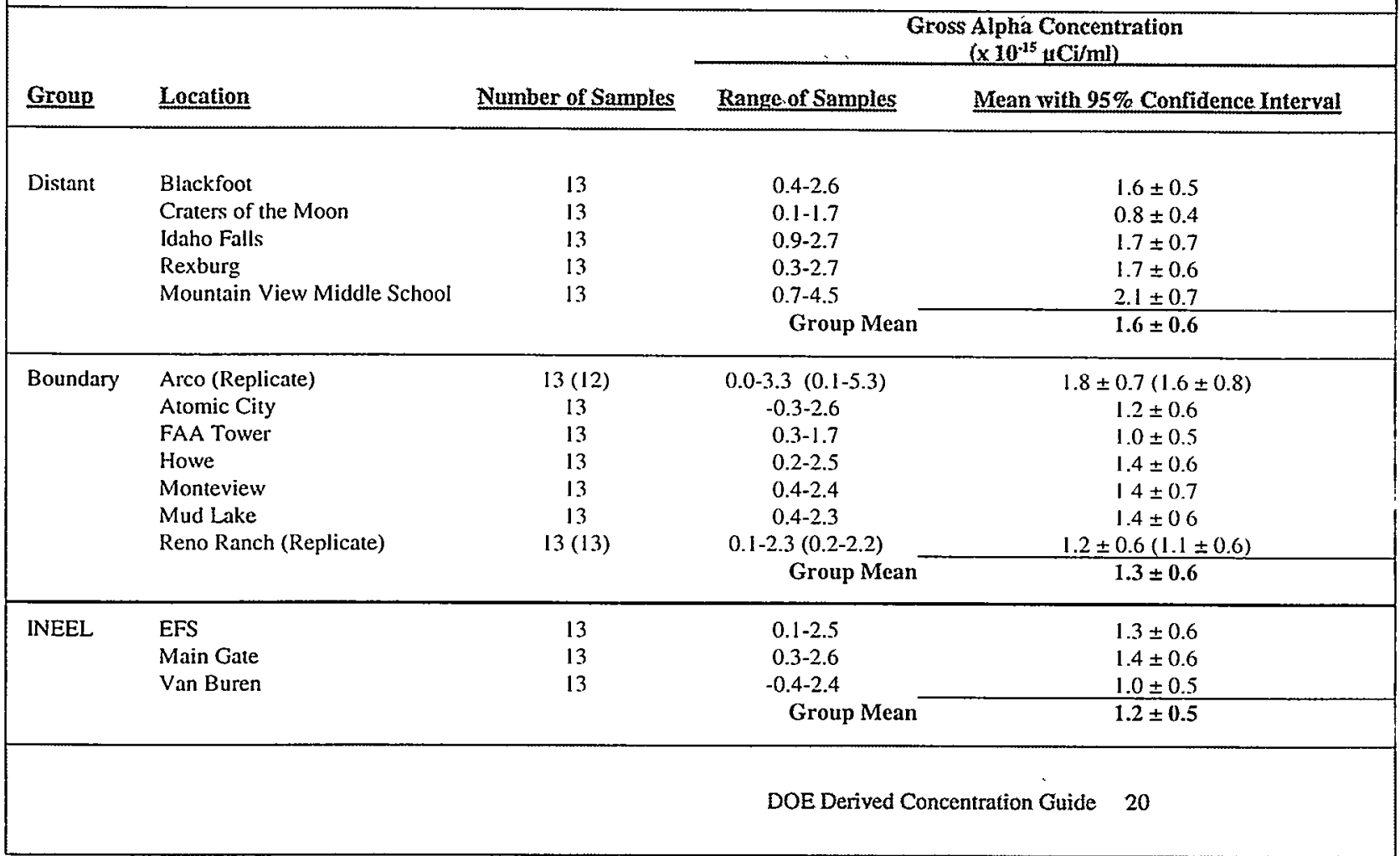

Table 2

Gross Beta Concentrations in Air Fourth Quarter 1998

\begin{tabular}{|c|c|c|c|c|}
\hline \multirow[b]{2}{*}{ Group } & \multirow[b]{2}{*}{ Location } & \multirow[b]{2}{*}{ Number of Samples } & \multicolumn{2}{|c|}{$\begin{array}{l}\text { Gross Beta Concentration } \\
\left(\times 10^{-15} \mathrm{u} \mathrm{Ci} / \mathrm{ml}\right)\end{array}$} \\
\hline & & & Range of Samples & Mean with $95 \%$ Confidence Interval \\
\hline Distant & $\begin{array}{l}\text { Blackfoot } \\
\text { Craters of the Moon } \\
\text { Idaho Falls } \\
\text { Rexburg } \\
\text { Mountain View Middle School }\end{array}$ & $\begin{array}{l}13 \\
13 \\
13 \\
13 \\
13\end{array}$ & $\begin{array}{c}9-37 \\
8-40 \\
12-44 \\
12-40 \\
8-47 \\
\text { Group Mean }\end{array}$ & $\begin{array}{l}22 \pm 2 \\
22 \pm 2 \\
27 \pm 2 \\
25 \pm 2 \\
24 \pm 2 \\
24 \pm 2\end{array}$ \\
\hline Boundary & $\begin{array}{l}\text { Arco (Replicate) } \\
\text { Atomic City } \\
\text { FAA Tower } \\
\text { Howe } \\
\text { Monteview } \\
\text { Mud Lake } \\
\text { Reno Ranch (Replicate) }\end{array}$ & $\begin{array}{c}13(12) \\
13 \\
13 \\
13 \\
13 \\
13 \\
13(13)\end{array}$ & $\begin{array}{c}11-43(12-40) \\
1-49 \\
11-43 \\
14-48 \\
11-41 \\
15-48 \\
11-45(9-39)\end{array}$ & $\begin{array}{c}25 \pm 2(22 \pm 2) \\
22 \pm 2 \\
20 \pm 2 \\
29 \pm 2 \\
27 \pm 2 \\
29 \pm 2 \\
24 \pm 2(25 \pm 2) \\
\end{array}$ \\
\hline & & & Group Mean & $25 \pm 2$ \\
\hline
\end{tabular}

4 


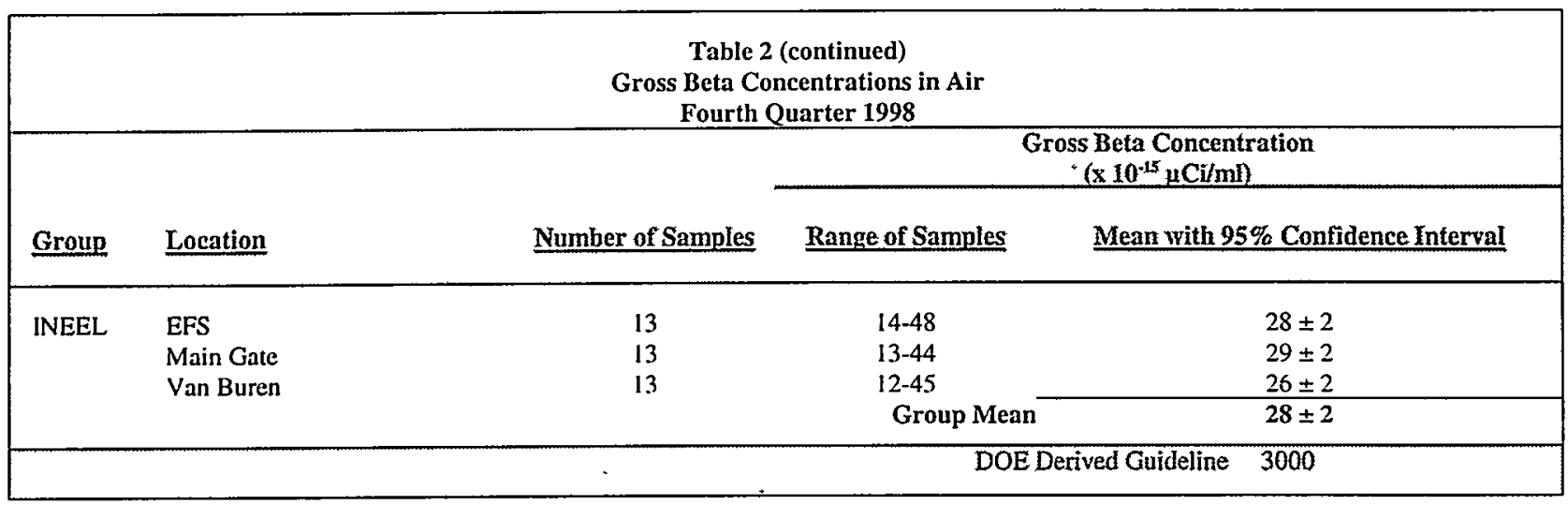

\section{2 $\mathrm{PM}_{10}$ Air Sampling}

Air sampling for respirable particulates continued at Madison Middle School (Rexburg), Mountain View Middle School (Blackfoot), and Atomic City. $\mathrm{PM}_{10}$ samplers were used to sample airborne particulates with an aerodynamic diameter smaller than 10 microns. Particles this size can penetrate the body's natural air filtering system and enter the lungs. These filters are not analyzed for radionuclides.

Samples were collected every sixth day from Rexburg, Blackfoot, and Atomic City. Concentrations at Rexburg ranged from 4 to $92 \mu \mathrm{g} / \mathrm{m}^{3}$, with an average of $26 \mu \mathrm{g} / \mathrm{m}^{3}$. At the Blackfoot location, values ranged from 2 to $26 \mu \mathrm{g} / \mathrm{m}^{3}$ with an average concentration of $11 \mu \mathrm{g} / \mathrm{m}^{3}$. In Atomic City the concentrations ranged from 3 to $92 \mu \mathrm{g} / \mathrm{m}^{3}$ with an average concentration of $18 \mu \mathrm{g} / \mathrm{m}^{3}$. The EPA standard is $150 \mu \mathrm{g} / \mathrm{m}^{3}$ averaged over 24 hours, and $50 \mu \mathrm{g} / \mathrm{m}^{3}$ averaged over the entire year.

\subsection{Atmospheric Moisture Sampling}

Four atmospheric moisture samples were obtained from Idaho Falls, Rexburg, Blackfoot and Atomic City during this reporting period. Samples were collected by passing air through a column of silica gel which absorbed water vapor. Tritium concentrations were determined by extracting water from the silica gel and counting the water sample by liquid scintillation. One sample from Idaho Falls contained a detectable level of tritium of $3.5 \pm 3.4 \mu \mathrm{Ci} / \mathrm{ml}$ of air. Detections at this low level can be attributed to worldwide cosmic tritium production or statistical fluctuations.

\subsection{Precipitation Sampling}

Thirteen precipitation samples were collected in the fourth quarter from Idaho Falls and from onsite locations at the Central Facilities Area (CFA) and the Experimental Field Station (EFS), and analyzed for tritium. Tritium was detected in one sample from EFS at a concentration of $1.1 \times 10^{-7} \mu \mathrm{Ci} / \mathrm{mL}$. These low concentrations may have been from INEEL operations, although they were consistent with concentrations attributed to natural causes. 


\section{Water Sampling}

Water samples were collected in November from 14 drinking water locations and four surface water locations in the Magic Valley area and Idaho Falls (Figure 4). Drinking water sampling locations were local businesses, while surface water locations included springs in the Thousand Springs area. These springs are some of the outlets for the Snake River Plain Aquifer, which flows beneath the INEEL. Samples were analyzed for gross alpha and gross beta activity by residue counting techniques. No samples showed measurable concentrations of tritium. A sample from Arco had detectable gross alpha activity. All of the samples contained detectable gross beta activity. Table 3 summarizes these findings. At these levels, radioactivity in water samples is generally attributed to naturally occurring decay products, sorbed by water as it flows through the earth's crust.

\begin{tabular}{|c|c|c|c|}
\hline \multicolumn{4}{|c|}{$\begin{array}{c}\text { Table } 3 \\
\begin{array}{c}\text { Radioactivity in Offsite Water Samples } \\
\text { Fourth Quarter } 1998\end{array}\end{array}$} \\
\hline Location & $\begin{array}{c}\text { Tritium } \\
(\mathrm{pCi} / 1 \pm 2 \mathrm{~s})\end{array}$ & $\begin{array}{c}\text { Gross Alpha } \\
\text { (pCi/l } \pm 2 \mathrm{~s})\end{array}$ & $\begin{array}{l}\text { Gross Beta } \\
(\mathrm{pCi} / 1 \pm 2 \mathrm{~s})\end{array}$ \\
\hline \multicolumn{4}{|c|}{ Drinking Water } \\
\hline $\begin{array}{l}\text { Aberdeen } \\
\text { Arco } \\
\text { Atomic City } \\
\text { Blackfoot } \\
\text { Carey } \\
\text { Fort Hall } \\
\text { Howe } \\
\text { Idaho Falls } \\
\text { Minidoka } \\
\text { Monteview } \\
\text { Mud Lake } \\
\text { Roberts } \\
\text { Shoshone } \\
\end{array}$ & $\begin{array}{r}-46 \pm 100 \\
80 \pm 100 \\
-53 \pm 100 \\
-15 \pm 100 \\
-53 \pm 100 \\
-52 \pm 100 \\
-55 \pm 100 \\
-80 \pm 100 \\
-50 \pm 100 \\
-69 \pm 100 \\
-46 \pm 100 \\
-93 \pm 100 \\
13 \pm 100\end{array}$ & $\begin{aligned} & 1 \pm 1 \\
& 1 \pm 1 \\
& 0 \pm 1 \\
& 0 \pm 1 \\
& 1 \pm 1 \\
& 0 \pm 1 \\
&-1 \pm 1 \\
& 0 \pm 1 \\
& 0 \pm 1 \\
& 0 \pm 1 \\
& 0 \pm 1 \\
& 0 \pm 1 \\
& 0 \pm 1 \\
&\end{aligned}$ & $\begin{aligned} & 8 \pm 2 \\
& 2 \pm 2 \\
& 3 \pm 2 \\
& 3 \pm 2 \\
& 3 \pm 2 \\
& 7 \pm 2 \\
& 2 \pm 2 \\
& 3 \pm 2 \\
& 4 \pm 2 \\
& 10 \pm 2 \\
& 3 \pm 2 \\
& 4 \pm 2 \\
& 3 \pm 2 \\
&\end{aligned}$ \\
\hline \multicolumn{4}{|c|}{ Surface Water } \\
\hline $\begin{array}{l}\text { Alpheus Spring (Twin Falls) } \\
\text { Bliss } \\
\text { Bill Jones Hatchery (Hagerman) } \\
\text { Clear Spring (Buhl) } \\
\text { Idaho Falls }\end{array}$ & $\begin{aligned} & 40 \pm 100 \\
&-100 \pm 100 \\
&-38 \pm 100 \\
&-100 \pm 100 \\
& 48 \pm 100 \\
&\end{aligned}$ & $\begin{array}{r}1 \\
0 \pm 1 \\
0 \pm 1 \\
-1 \pm 1 \\
0 \pm 1 \\
\end{array}$ & $\begin{array}{l}9 \pm 2 \\
4 \pm 2 \\
4 \pm 2 \\
6 \pm 2 \\
4 \pm 2\end{array}$ \\
\hline EPA Maximum Contaminant Level & 20,000 & 15 & 50 \\
\hline
\end{tabular}

\section{Foodstuff Sampling}

Foodstuff sampling locations are shown in Figure 4. Milk samples were collected weekly in Idaho Falls and monthly at eight other locations around the INEEL (Figure 4). Two types of locations were sampled: single family dairies and large commercial dairies. Each milk sample was analyzed for ${ }^{131} \mathrm{I}$ by gamma spectrometry. Results were decay-corrected to the time of sample collection. A total of 38 milk samples were collected during the fourth quarter. None of the 
samples exhibited detectable concentrations of

${ }^{131}$ I. Of four samples selected for radiochemical analysis, strontium-90 was found only in the Dietrich area at a concentration of $(6.8 \pm 3.3) \times 10^{-4} \mathrm{pCi} / \mathrm{mL}$. This concentration is consistent with concentrations found in milk throughout the world. Sources include fallout from historic above ground nuclear testing, and past nuclear accidents such as Chernobyl.

Seven potato samples were collected during

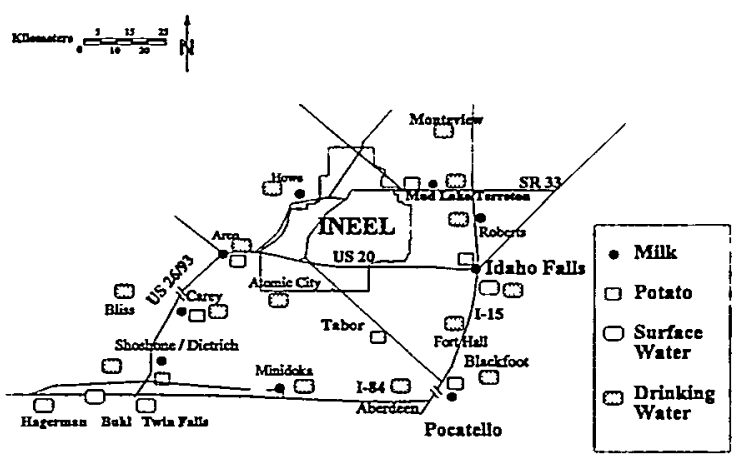
the fourth quarter of 1998 , four from distant locations and three from boundary locations. Strontium-90 was detected in the sample from Monteview at a concentration of $(5.8 \pm 5.1) \times 10^{-3} \mathrm{pCi} / \mathrm{g}$, the sample from Blackfoot at $(3.2 \pm 2.6) \times 10^{-3} \mathrm{pCi} / \mathrm{g}$ and in the sample from Arco at a concentration of $(5.4 \pm 3.6) \times 10^{-3} \mathrm{pCi} / \mathrm{g}$. These concentrations are consistent with past results seen in potatoes and are likely due to historic worldwide fallout from nuclear weapons testing and reactor accidents.

Two elk and five mule deer were killed accidentally on INEEL roads during the fourth quarter of 1998, and tissue samples of muscle, thyroid, and liver were collected from each of these animals and subjected to gamma spectroscopic analysis. Muscle samples from one of the elk and four of the mule deer contained low but detectable concentrations of cesium-137, and a liver sample from one mule deer also contained detectable cesium-137. No iodine-137 was found in any of the thyroid samples. Table 4 shows the detectable concentrations of radionuclides found in these animals. These small concentrations are within the range of values observed in past wild game samples and can be attributed to the ingestion of radionuclides from worldwide fallout from aboveground nuclear weapons testing.

\begin{tabular}{|c|c|c|c|}
\hline \multicolumn{4}{|c|}{$\begin{array}{c}\text { Table } 4 \\
\text { Cesium-137 Concentrations in Road-Killed Wild Game } \\
\text { Fourth Quarter } 1998\end{array}$} \\
\hline Collection Date & Species & $\underline{\text { Tissue }}$ & $\begin{array}{l}\text { Cs-137 Concentration } \\
\left(\mu \mathrm{Ci} / \mathrm{g} \times 10^{*} \pm 2 \mathrm{~s}\right) \\
\end{array}$ \\
\hline $10 / 05 / 98$ & Mule Deer & Muscle & $1.2 \pm 0.3$ \\
\hline $10 / 15 / 98$ & Mule Deer & Muscle & $1.6 \pm 0.3$ \\
\hline $11 / 30 / 98$ & Mule Deer & Muscle & $1.7 \pm 0.3$ \\
\hline $11 / 30 / 98$ & Mule Deer & Liver & $1.3 \pm 0.4$ \\
\hline $12 / 10 / 98$ & Elk & Muscle & $0.2 \pm 0.2$ \\
\hline $12 / 15 / 98$ & Mule Deer & Muscle & $0.4 \pm 0.2$ \\
\hline
\end{tabular}




\section{Environmental Radiation}

Thermoluminescent dosimeters (TLDs), changed semiannually, were collected from six boundary and eight distant locations (Figure 5). TLD measurements for the second half of 1998 (May 1998-October 1998) show similar exposure levels to the previous six-month interval (Table 5). There were no statistically significant differences between the distant and boundary groups.

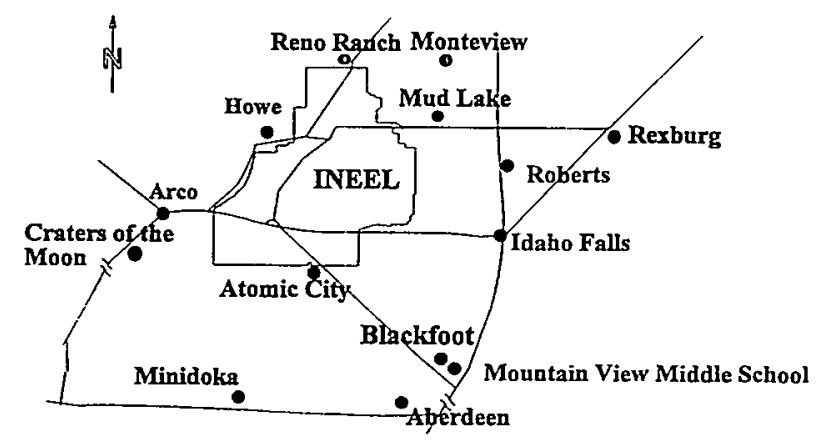

Figure 5 TLD Locations

\begin{tabular}{|c|c|c|c|}
\hline \multicolumn{4}{|c|}{$\begin{array}{l}\text { Table } 5 \\
\text { Radiation Exposures at Distant and Boundary Locations (1998) }\end{array}$} \\
\hline Location & ' & Exposure $(\mathrm{mR} \pm 2 \mathrm{~s})$ & . \\
\hline & $\begin{array}{l}\text { Nov. } 1997- \\
\text { May } 1998\end{array}$ & $\begin{array}{l}\text { May } 1998- \\
\text { Oct. } 1998 \\
\end{array}$ & Annual Total \\
\hline \multicolumn{4}{|c|}{ Distant Locations } \\
\hline Aberdeen & $62 \pm 7$ & $66 \pm 3$ & $128 \pm 8$ \\
\hline Blackfoot & $65 \pm 4$ & $65 \pm 4$ & $130 \pm 6$ \\
\hline Craters of the Moon & $56 \pm 4$ & $66 \pm 5$ & $122 \pm 6$ \\
\hline Idaho Falls & $64 \pm 5$ & $60 \pm 4$ & $124 \pm 6$ \\
\hline Minidoka & $57 \pm 5$ & $59 \pm 5$ & $116 \pm 7$ \\
\hline Rexburg & $71 \pm 6$ & $73 \pm 3$ & $144 \pm 7$ \\
\hline Roberts & $61 \pm 4$ & $69 \pm 4$ & $130 \pm 6$ \\
\hline Mountain View Middle School & $56 \pm 2$ & $57 \pm 4$ & $113 \pm 4$ \\
\hline Group Mean & $62 \pm 9$ & $64 \pm 8$ & $126 \pm 12$ \\
\hline \multicolumn{4}{|c|}{ Boundary Locations } \\
\hline Arco & $65 \pm 6$ & $63 \pm 3$ & $128 \pm 7$ \\
\hline Atomic City & $66 \pm 4$ & $66 \pm 4$ & $132 \pm 6$ \\
\hline Howe & $62 \pm 2$ & $63 \pm 5$ & $125 \pm 5$ \\
\hline Monteview & $61 \pm 2$ & $63 \pm 3$ & $124 \pm 4$ \\
\hline Mud Lake & $69 \pm 6$ & $68 \pm 3$ & $137 \pm 7$ \\
\hline Reno Ranch & $61 \pm 4$ & $56 \pm 5$ & $117 \pm 6$ \\
\hline Group Mean & $64 \pm 9$ & $63 \pm 8$ & $127 \pm 12$ \\
\hline
\end{tabular}




\section{Appendix A Summary \\ of \\ Environmental Surveillance Networks}

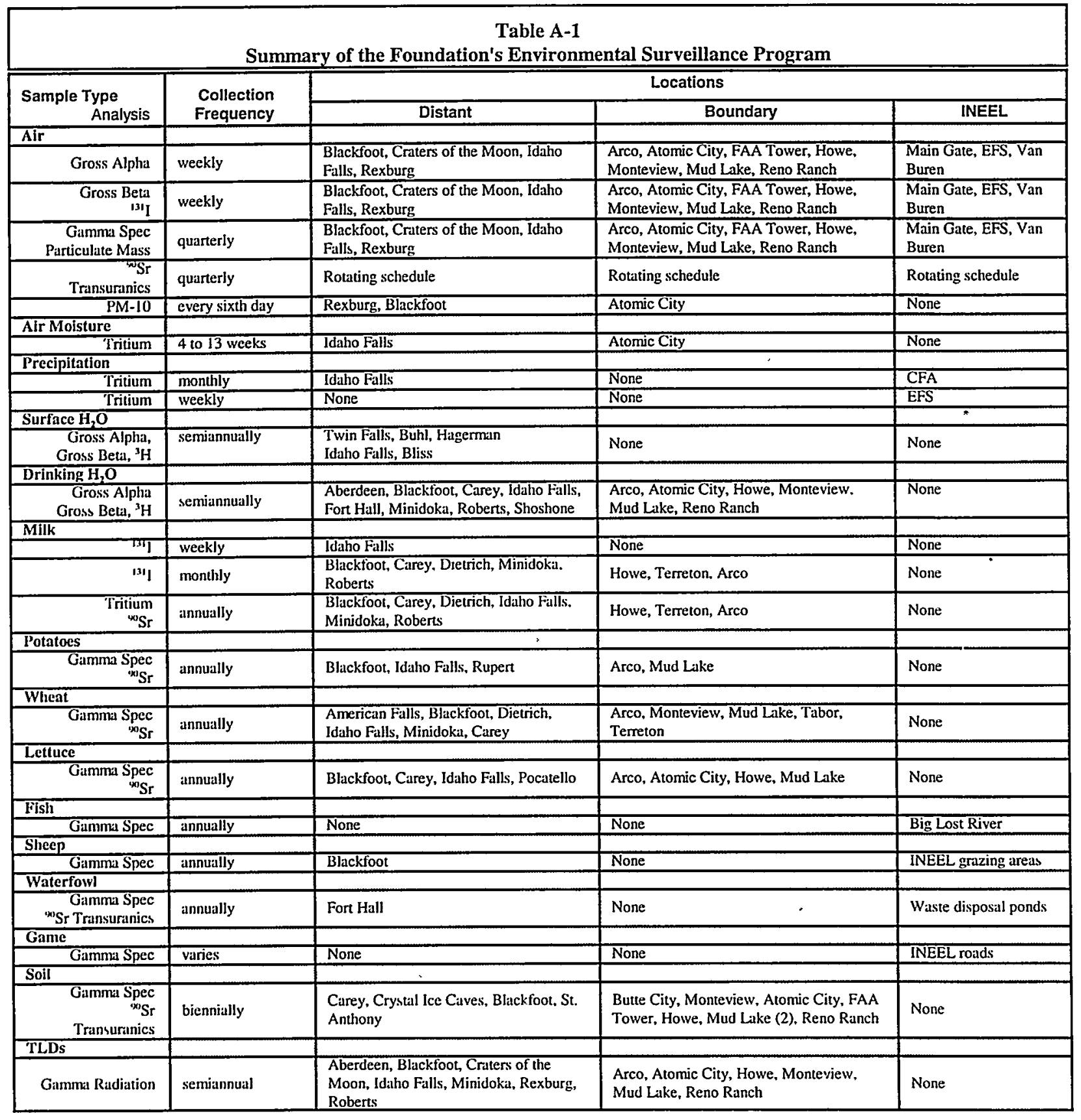




\begin{tabular}{|c|c|c|c|c|}
\hline \multicolumn{5}{|c|}{$\begin{array}{c}\text { Table A-2 } \\
\text { Summary of Approximate Minimum Detectable Concentrations for Radiological Analyses }\end{array}$} \\
\hline Sample Type & Analysis & $\begin{array}{c}\frac{\text { Approximate Minimum }}{\text { Detectable }} \\
\frac{\text { Concentration }}{4} \\
\text { (MDC) }\end{array}$ & $\frac{\underline{\text { Derived }}}{\text { Concentration Guide }^{\mathrm{s}}}$ & $\frac{\text { Drinking Water }}{\text { Detection Limits }^{2}}$ \\
\hline \multirow[t]{7}{*}{ Air (particulate filter) ${ }^{d}$} & Gross alpha & $1 \times 10^{-15} \mu \mathrm{Ci} / \mathrm{ml}$ & $2 \times 10^{-14} \mu \mathrm{Ci} / \mathrm{ml}$ & 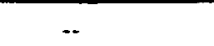 \\
\hline & Gross beta & $3 \times 10^{-15} \mu \mathrm{Ci} / \mathrm{ml}$ & $3 \times 10^{-12} \mu \mathrm{Ci} / \mathrm{ml}$ & - \\
\hline & $\begin{array}{l}\text { Specific gamma } \\
\left({ }^{1{ }^{177}} \mathrm{Cs}\right)\end{array}$ & $3 \times 10^{-16} \mu \mathrm{Ci} / \mathrm{ml}$ & $4 \times 10^{-111} \mu \mathrm{Ci} / \mathrm{ml}$ & \\
\hline & ${ }^{237} \mathrm{Pu}$ & $2 \times 10^{-18} \mu \mathrm{Ci} / \mathrm{ml}$ & $3 \times 10^{-14} \mu \mathrm{Ci} / \mathrm{ml}$ & \\
\hline & ${ }^{23}{ }^{3} / 241 \mathrm{Pu}$ & $3 \times 10^{-18} \mu \mathrm{Ci} / \mathrm{ml}$ & $2 \times 10^{-14} \mu \mathrm{Ci} / \mathrm{ml}$ & \\
\hline & ${ }^{241} \mathrm{Am}$ & $2 \times 10^{-18} \mu \mathrm{Ci} / \mathrm{ml}$ & $2 \times 10^{-14} \mu \mathrm{Ci} / \mathrm{ml}$ & $\ldots$ \\
\hline & ${ }^{4 r} \mathrm{Sr}$ & $3 \times 10^{-17} \mu \mathrm{Ci} / \mathrm{ml}$ & $9 \times 10^{-12} \mu \mathrm{Ci} / \mathrm{ml}$ & -- \\
\hline Air (charcoal cartridge) & ${ }^{131} \mathrm{I}$ & $4 \times 10^{-15} \mu \mathrm{Ci} / \mathrm{ml}$ & $4 \times 10^{-111} \mu \mathrm{Ci} / \mathrm{ml}$ & -- \\
\hline Air (atmospheric moisture) & ${ }^{3} \mathrm{H}$ & $4 \times 10^{-12} \mu \mathrm{Ci} / \mathrm{ml}$ & $1 \times 10^{-7} \mu \mathrm{Ci} / \mathrm{ml}$ & -- \\
\hline Air (precipitation) & ${ }^{3} \mathrm{H}$ & $1 \times 10^{-7} \mu \mathrm{Ci} / \mathrm{ml}$ & $2 \times 10^{-3} \mu \mathrm{Ci} / \mathrm{ml}$ & -. \\
\hline \multirow[t]{3}{*}{ Water (drinking \& surface) } & Gross alpha & $3 \mathrm{pCi} / \mathrm{l}$ & $30 \mathrm{pCi} / !$ & $3 \mathrm{pCi} / 1$ \\
\hline & Gross beta & $2 \mathrm{pCi} / 1$ & $100 \mathrm{pCi} / 1$ & $4 \mathrm{pCi} / 1$ \\
\hline & ${ }^{3} \mathrm{H}$ & $100 \mathrm{pCi} / 1$ & $2 \times 10^{6} \mathrm{pCi} / \mathrm{l}$ & $1000 \mathrm{pCi} / \mathrm{I}$ \\
\hline Milk & ${ }^{131} \mathrm{I}$ & $3 \times 10^{-9} \mu \mathrm{Ci} / \mathrm{ml}$ & -- & -- \\
\hline \multirow[t]{2}{*}{ Wheat } & $\begin{array}{l}\text { Specific gamma } \\
\left({ }^{137} \mathrm{Cs}\right)\end{array}$ & $4 \times 10^{-9} \mu \mathrm{Ci} / \mathrm{g}$ & -- & -- \\
\hline & ${ }^{*} \mathrm{Sr} r$ & $5 \times 10^{-9} \mu \mathrm{Ci} / \mathrm{g}$ & - & -- \\
\hline \multirow[t]{2}{*}{ Lettuce } & $\begin{array}{l}\text { Specific gamma } \\
\left({ }^{177} \mathrm{Cs}\right)\end{array}$ & $1 \times 10^{-7} \mu \mathrm{Ci} / \mathrm{g}$ & -- & -- \\
\hline & ${ }^{90} \mathrm{Sr}$ & $2 \times 10^{-7} \mu \mathrm{Ci} / \mathrm{g}$ & -- & -- \\
\hline \multicolumn{5}{|c|}{ 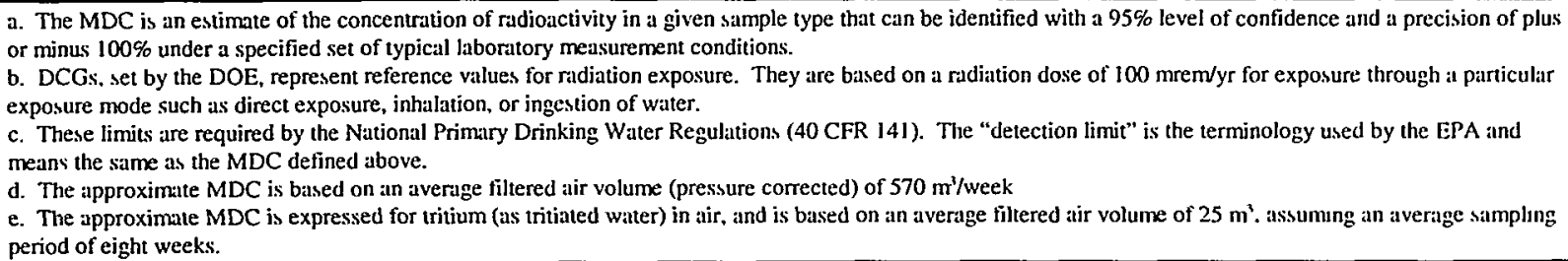 } \\
\hline
\end{tabular}




\section{Appendix B \\ Helpful Information for Readers}

\section{Radionuclide Nomenclature}

Radionuclides are sometimes expressed with the one- or two-letter chemical symbol for the element. A radionuclide is an unstable, or radioactive, form of an element. A given element may have many different radionuclides. Each is designated by a superscript number to the left of the chemical symbol. This number is the atomic weight of the radionuclide, equal to the number of protons and neutrons in its nucleus. Radionuclides which may be used in this report are shown in the following table:

\begin{tabular}{|c|c|c|c|}
\hline Symbol & $\underline{\text { Radionuclide }}$ & Symbol & Radionuclide \\
\hline${ }^{3} \mathrm{H}$ & Tritium & $\begin{array}{l}{ }_{131}^{131} \\
{ }^{124} \mathrm{Cc}\end{array}$ & lodine-131 \\
\hline "Cr & $\begin{array}{l}\text { Beryllum- } \\
\text { Chromium-51 }\end{array}$ & ${ }^{137} \mathrm{Cs}$ & Cesium-137 \\
\hline${ }^{54} \mathrm{Mn}$ & Manganese-54 & ${ }^{144} \mathrm{Ce}$ & Cerium-144 \\
\hline${ }^{9 \kappa} \mathrm{Co}$ & Cobalt -58 & ${ }^{1 \mathrm{kl}} \mathrm{Hf}$ & Hafnium-181 \\
\hline "No $\mathrm{Co}$ & Cobalt -60 & ${ }^{22 x} \mathrm{Pu}$ & Plutonium-238 \\
\hline " $\mathrm{Zn}$ & Zinc- 65 & 23912411 Pu & Plutonium-239/240 \\
\hline${ }^{n /} \mathrm{Sr}$ & Strontium-90 & ${ }^{241} \mathrm{Am}$ & Americium-241 \\
\hline${ }^{\circ 5} \mathrm{Nb}$ & Niobium-95 & & \\
\hline
\end{tabular}

\section{Scientific Notation}

Scientific notation is used to express numbers which are very small and very large. A very small number will be expressed with a negative exponent, e.g., $1.3 \times 10^{-6}$. To convert this number to the more commonly used form, the decimal point must be moved left by the number of places equal to the exponent (in this case, six). The number thus becomes 0.0000013 .

For large numbers, those with a positive exponent, the decimal point is moved to the right by the number of places equal to the exponent. The number $1,000,000$ (or one million) can be written as $1.0 \mathrm{x}$ $10^{6}$.

\section{Unit Prefixes}

Units for very small and very large numbers are commonly expressed with a prefix. One example is the prefix kilo, abbreviated $\mathrm{k}$, which means 1,000 of a given unit. A kilometer is therefore equal to 1,000 meters. Prefixes that may be used in this report are:

$\begin{array}{ccc}\text { Prefix } & \text { Abbreviation } & \text { Meaning } \\ \text { milli } & \mathrm{m} & 1 / 1,000\left(=1 \times 10^{-3}\right) \\ \text { micro } & \mu & 1 / 1,000,000\left(=1 \times 10^{-6}\right) \\ \text { pico } & \mathrm{p} & 1 / 1.000,000,000,000\left(=1 \times 10^{-12}\right)\end{array}$

\section{Units of Radioactivity and Radiation Exposure and Dose}

The basic unit of radioactivity used in this report is the curie, abbreviated $\mathrm{Ci}$. The curie is defined as the amount of radioactivity equivalent to 37 billion nuclear transformations per second. 
Historically, this was based upon the radioactivity from one gram of the radionuclide Radium-226. For any other radionuclide, one curie is the amount of that radionuclide that decays at this same rate.

Radiation exposure is expressed in terms of the Roentgen $(R)$, the amount of ionization produced by gamma radiation in air. Dose is given in units of "Roentgen equivalent man," or "rem," which takes into account the effect of radiation on tissues. For the types of environmental radiation generally encountered, the unit of Roentgen is approximately numerically equal to the unit of rem.

\section{Units of Environmental Concentrations}

Concentration of radioactivity in air and milk samples are expressed in units of microcuries per milliliter $(\mu \mathrm{Ci} / \mathrm{ml})$. Concentrations in water samples are expressed as picocuries per liter $(\mathrm{pCi} / \mathrm{l})$; federal standards are expressed in these units. Radioactivity in foodstuffs are given in microcuries per gram $(\mu \mathrm{Ci} / \mathrm{g})$, dry weight. Radioactivity in soil samples is expressed as picocuries per gram (pCi/g), dry weight. Annual human radiation exposure, measured by environmental dosimeters, is expressed in units of milliRoentgens (mR). This is sometimes expressed in terms of dose as millirem (mrem).

\section{Uncertainty of Measurements}

Due to many variables, there is always an uncertainty associated with the measurement of environmental contaminants. For radioactivity, the predominant source of uncertainty is due to the inherent statistical nature of radioactive decay events, particularly at the low activity levels encountered in environmental samples. The uncertainty of a measurement is denoted by following the result with a " \pm " (uncertainty) term. This report follows convention in reporting the uncertainty as a $95 \%$ confidence limit (or interval), designated in the tables as " $\pm 2 \mathrm{~s}$." That means there is approximately a $95 \%$ level of confidence that the real concentration in the sample lies somewhere between the measured (reported) concentration minus the uncertainty term and the measured (reported) concentration plus the uncertainty term.

\section{Negative Numbers as Results}

Environmental measurements are frequently conducted at levels where the contaminant, such as radioactivity, cannot be distinguished from natural background levels. In this case, the result will still be reported by the analytical laboratory, even though it is below the measurement system's approximate minimum detectable concentration, or is less than zero. Negative values occur when the measured result is less than a pre-established average background level for the particular system and procedure used. These values, rather than "not detectable" or "zero," are reported to better enable statistical analyses and to observe trends in the data.

\section{Gross versus Specific Analyses}

Many of the radiological analyses of environmental samples yield information only about the overall, or gross, amount of a particular type of radiation (e.g., gross beta), rather than identifying and quantifying specific radionuclides. For example, rather than performing an analysis for particular gamma-emitting radionuclides, called gamma spectroscopy, one can do a gross gamma or, more commonly, a gross beta analysis, since gamma-emitting radionuclides also emit beta particles. This type of analysis is an effective screening tool and is much quicker and less costly than specific radionuclide analyses. 


\section{Appendix $\mathbf{C}$ \\ Weekly Gross Alpha and Gross Beta Concentrations in Air $4^{\text {th }}$ Quarter 1998}

\begin{tabular}{|c|c|c|c|}
\hline Location & Collection Date & 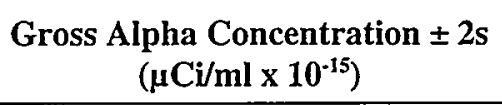 & $\begin{array}{c}\text { Gross Beta Concentration } \pm 2 \mathrm{~s} \\
\left(\mu \mathrm{Ci} / \mathrm{ml} \mathrm{x} \mathrm{10}^{-15}\right)\end{array}$ \\
\hline Blackfoot & $10 / 07 / 98$ & $2.1 \pm 0.6$ & $18 \pm 1$ \\
\hline \multirow[t]{12}{*}{ NOAA } & $10 / 14 / 98$ & $2.6 \pm 0.7$ & $27 \pm 2$ \\
\hline & $10 / 21 / 98$ & $1.5 \pm 0.5$ & $15 \pm 1$ \\
\hline & $10 / 28 / 98$ & $2.3 \pm 0.6$ & $37 \pm 2$ \\
\hline & $11 / 04 / 98$ & $2.5 \pm 0.6$ & $25 \pm 2$ \\
\hline & $11 / 11 / 98$ & $1.6 \pm 0.8$ & $13 \pm 2$ \\
\hline & $11 / 18 / 98$ & $1.1 \pm 0.5$ & $23 \pm 2$ \\
\hline & $11 / 24 / 98$ & $1.1 \pm 0.5$ & $15 \pm 2$ \\
\hline & $12 / 02 / 98$ & $1.8 \pm 0.5$ & $16 \pm 1$ \\
\hline & $12 / 09 / 98$ & $0.4 \pm 0.5$ & $9 \pm 1$ \\
\hline & $12 / 16 / 98$ & $0.6 \pm 0.4$ & $22 \pm 2$ \\
\hline & $12 / 23 / 98$ & $1.5 \pm 0.6$ & $33 \pm 2$ \\
\hline & $12 / 30 / 98$ & $1.6 \pm 0.5$ & $29 \pm 2$ \\
\hline \multirow{13}{*}{$\begin{array}{l}\text { Craters of } \\
\text { the Moon }\end{array}$} & $10 / 07 / 98$ & $1.1 \pm 0.5$ & $20 \pm 2$ \\
\hline & $10 / 14 / 98$ & $1.4 \pm 0.5$ & $22 \pm 2$ \\
\hline & $10 / 21 / 98$ & $0.7 \pm 0.4$ & $17 \pm 1$ \\
\hline & $10 / 28 / 98$ & $1.7 \pm 0.6$ & $40 \pm 2$ \\
\hline & $11 / 04 / 98$ & $1.0 \pm 0.4$ & $26 \pm 2$ \\
\hline & $11 / 11 / 98$ & $1.2 \pm 0.8$ & $14 \pm 2$ \\
\hline & $11 / 18 / 98$ & $0.5 \pm 0.4$ & $24 \pm 2$ \\
\hline & $11 / 24 / 98$ & $0.2 \pm 0.3$ & $11 \pm 1$ \\
\hline & $12 / 02 / 98$ & $0.5 \pm 0.3$ & $15 \pm 1$ \\
\hline & $12 / 09 / 98$ & $0.1 \pm 0.3$ & $8 \pm 1$ \\
\hline & $12 / 16 / 98$ & $0.5 \pm 0.4$ & $25 \pm 2$ \\
\hline & $12 / 23 / 98$ & $0.4 \pm 0.4$ & $33 \pm 2$ \\
\hline & $12 / 30 / 98$ & $1.2 \pm 0.5$ & $27 \pm 2$ \\
\hline \multirow[t]{12}{*}{ Idaho Falls } & $10 / 07 / 98$ & $1.6 \pm 0.7$ & $21 \pm 2$ \\
\hline & $10 / 14 / 98$ & $1.6 \pm 0.6$ & $28 \pm 2$ \\
\hline & $10 / 21 / 98$ & $2.2 \pm 0.7$ & $18 \pm 2$ \\
\hline & $10 / 28 / 98$ & $2.6 \pm 0.8$ & $44 \pm 3$ \\
\hline & $11 / 04 / 98$ & $2.7 \pm 0.8$ & $28 \pm 2$ \\
\hline & $11 / 11 / 98$ & $1.8 \pm 1.1$ & $19 \pm 2$ \\
\hline & $11 / 18 / 98$ & $1.7 \pm 0.7$ & $35 \pm 3$ \\
\hline & $11 / 24 / 98$ & $0.9 \pm 0.6$ & $18 \pm 2$ \\
\hline & $12 / 02 / 98$ & $1.0 \pm 0.5$ & $18 \pm 2$ \\
\hline & $12 / 09 / 98$ & $1.1 \pm 0.6$ & $12 \pm 2$ \\
\hline & $12 / 16 / 98$ & $1.1 \pm 0.7$ & $32 \pm 3$ \\
\hline & $12 / 23 / 98$ & $1.6 \pm 0.7$ & $35 \pm 3$ \\
\hline
\end{tabular}




\section{Appendix C \\ Weekly Gross Alpha and Gross Beta Concentrations in Air $4^{\text {th }}$ Quarter 1998}

Location Collection Date

$12 / 30 / 98$

Rexburg

$10 / 07 / 98$

$10 / 14 / 98$

$10 / 21 / 98$

$10 / 28 / 98$

$11 / 04 / 98$

$11 / 11 / 98$

$11 / 18 / 98$

$11 / 24 / 98$

$12 / 02 / 98$

$12 / 09 / 98$

$12 / 16 / 98$

$12 / 23 / 98$

$12 / 30 / 98$

Mountain $\quad 10 / 07 / 98$

View

Middle

School

(Blackfoot)
Gross Alpha Concentration $\pm 2 \mathrm{~s}$

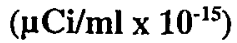

Gross Beta Concentration $\pm 2 \mathrm{~s}$ $\left(\mu \mathrm{Ci} / \mathrm{ml} \mathrm{x} \mathrm{10^{-15 } )}\right.$
$1.9 \pm 0.7 \quad 43 \pm 3$

$2.1 \pm 0.6$

$2.1 \pm 0.6$

$2.7 \pm 0.7$

$2.2 \pm 0.7$

$2.6 \pm 0.7$

$1.5 \pm 0.9$

$1.8 \pm 0.6$

$1.0 \pm 0.6$

$1.6 \pm 0.5$

$0.3 \pm 0.4$

$1.0 \pm 0.5$

$1.7 \pm 0.6$

$1.3 \pm 0.6$

$1.8 \pm 0.6$

$2.9 \pm 0.7$

$1.4 \pm 0.5$

$2.9 \pm 0.8$

$4.5 \pm 0.9$

$1.9 \pm 1.0$

$2.6 \pm 0.8$

$2.6 \pm 0.7$

$1.6 \pm 0.5$

$0.7 \pm 0.5$

$1.8 \pm 0.6$

$1.4 \pm 0.6$

$1.4 \pm 0.5$

$2.2 \pm 0.7$

$2.7 \pm 0.8$

$1.5 \pm 0.6$

$3.3 \pm 0.9$

$2.7 \pm 0.8$

$2.2 \pm 1.2$

$1.7 \pm 0.7$

$1.7 \pm 0.8$

$0.4 \pm 0.4$

$0.0 \pm 0.4$

$1.4 \pm 0.6$
$23 \pm 2$

$27 \pm 2$

$18 \pm 2$

$40 \pm 2$

$28 \pm 2$

$19 \pm 2$

$28 \pm 2$

$16 \pm 2$

$19 \pm 2$

$12 \pm 1$

$28 \pm 2$

$33 \pm 2$

$28 \pm 2$

$18 \pm 2$

$28 \pm 2$

$14 \pm 2$

$47 \pm 3$

$30 \pm 2$

$18 \pm 2$

$32 \pm 2$

$19 \pm 2$

$16 \pm 1$

$8 \pm 1$

$24 \pm 2$

$35 \pm 2$

$26 \pm 2$

$17 \pm 2$

$30 \pm 2$

$16 \pm 2$

$43 \pm 3$

$33 \pm 2$

$20 \pm 2$

$31 \pm 2$

$16 \pm 2$

$18 \pm 2$

$11 \pm 1$

$27 \pm 2$ 


\section{Appendix C \\ Weekly Gross Alpha and Gross Beta Concentrations in Air $4^{\text {th }}$ Quarter 1998}

\begin{tabular}{|c|c|c|c|}
\hline Location & Collection Date & $\begin{array}{l}\text { Gross Alpha Concentration } \pm 2 \mathrm{~s} \\
\left(\mu \mathrm{Ci} / \mathrm{ml} \times 10^{-15}\right)\end{array}$ & 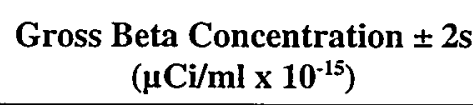 \\
\hline Arco & $12 / 23 / 98$ & $1.4 \pm 0.6$ & $25 \pm 2$ \\
\hline (cont.) & $12 / 30 / 98$ & $1.8 \pm 0.7$ & $40 \pm 3$ \\
\hline Arco & 10/07/98 & $0.9 \pm 0.4$ & $13 \pm 1$ \\
\hline \multirow[t]{12}{*}{ Replicate } & $10 / 14 / 98$ & $1.5 \pm 0.6$ & $27 \pm 2$ \\
\hline & $10 / 21 / 98$ & $1.4 \pm 0.5$ & $16 \pm 1$ \\
\hline & $10 / 28 / 98$ & $2.1 \pm 0.7$ & $40 \pm 2$ \\
\hline & $11 / 04 / 98$ & $1.7 \pm 0.5$ & $14 \pm 1$ \\
\hline & $11 / 11 / 98$ & $5.3 \pm 2.1$ & $20 \pm 3$ \\
\hline & $11 / 18 / 98$ & \multicolumn{2}{|c|}{ Invalid sample due to pump failure } \\
\hline & $11 / 24 / 98$ & $0.4 \pm 0.6$ & $22 \pm 2$ \\
\hline & $12 / 02 / 98$ & $0.8 \pm 0.4$ & $16 \pm 1$ \\
\hline & $12 / 09 / 98$ & $0.1 \pm 0.3$ & $12 \pm 1$ \\
\hline & $12 / 16 / 98$ & $1.2 \pm 0.5$ & $31 \pm 2$ \\
\hline & $12 / 23 / 98$ & $1.8 \pm 0.6$ & $32 \pm 2$ \\
\hline & $12 / 30 / 98$ & $1.6 \pm 0.5$ & $26 \pm 2$ \\
\hline \multirow[t]{13}{*}{ Atomic City } & $10 / 07 / 98$ & $1.1 \pm 0.5$ & $18 \pm 2$ \\
\hline & $10 / 14 / 98$ & $1.9 \pm 0.7$ & $33 \pm 2$ \\
\hline & $10 / 21 / 98$ & $1.1 \pm 0.5$ & $18 \pm 2$ \\
\hline & $10 / 28 / 98$ & $2.6 \pm 0.8$ & $49 \pm 3$ \\
\hline & $11 / 04 / 98$ & $1.0 \pm 0.8$ & $17 \pm 3$ \\
\hline & $11 / 11 / 98$ & $1.5 \pm 0.9$ & $19 \pm 2$ \\
\hline & $11 / 18 / 98$ & $0.9 \pm 0.5$ & $32 \pm 2$ \\
\hline & $11 / 24 / 98$ & $1.3 \pm 0.6$ & $21 \pm 2$ \\
\hline & $12 / 02 / 98$ & $1.1 \pm 0.5$ & $18 \pm 2$ \\
\hline & $12 / 09 / 98$ & $-0.3 \pm 0.8$ & $6 \pm 2$ \\
\hline & $12 / 16 / 98$ & $0.3 \pm 0.4$ & $27 \pm 2$ \\
\hline & $12 / 23 / 98$ & $1.6 \pm 0.6$ & $32 \pm 2$ \\
\hline & $12 / 30 / 98$ & $1.0 \pm 0.5$ & $1 \pm 1$ \\
\hline \multirow[t]{10}{*}{ Howe } & $10 / 07 / 98$ & $1.0 \pm 0.5$ & $18 \pm 2$ \\
\hline & $10 /[4 / 98$ & $1.8 \pm 0.5$ & $26 \pm 2$ \\
\hline & $10 / 21 / 98$ & $1.2 \pm 0.5$ & $18 \pm 2$ \\
\hline & $10 / 28 / 98$ & $2.5 \pm 0.6$ & $41 \pm 2$ \\
\hline & $11 / 04 / 98$ & $1.7 \pm 0.6$ & $35 \pm 2$ \\
\hline & $11 / 11 / 98$ & $2.1 \pm 1.0$ & $22 \pm 2$ \\
\hline & $11 / 18 / 98$ & $1.5 \pm 0.6$ & $45 \pm 3$ \\
\hline & $11 / 24 / 98$ & $0.2 \pm 0.4$ & $14 \pm 2$ \\
\hline & $12 / 02 / 98$ & $0.8 \pm 0.4$ & $20 \pm 2$ \\
\hline & $12 / 09 / 98$ & $0.5 \pm 0.4$ & $15 \pm 1$ \\
\hline
\end{tabular}




\section{Appendix $\mathbf{C}$ \\ Weekly Gross Alpha and Gross Beta Concentrations in Air $4^{\text {th }}$ Quarter 1998}

\begin{tabular}{|c|c|c|c|}
\hline Location & Collection Date & $\begin{array}{l}\text { Gross Alpha Concentration } \pm 2 \mathrm{~s} \\
\left(\mu \mathrm{Ci} / \mathrm{ml} \times 10^{-15}\right)\end{array}$ & 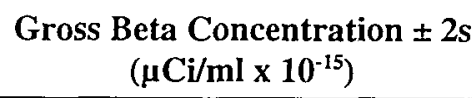 \\
\hline Howe & $12 / 16 / 98$ & $0.8 \pm 0.5$ & $36 \pm 2$ \\
\hline \multirow[t]{2}{*}{ (cont.) } & $12 / 23 / 98$ & $1.5 \pm 0.6$ & $38 \pm 2$ \\
\hline & $12 / 30 / 98$ & $2.1 \pm 0.7$ & $48 \pm 3$ \\
\hline FAA & $10 / 07 / 98$ & $1.1 \pm 0.5$ & $14 \pm 1$ \\
\hline \multirow[t]{12}{*}{ Tower } & $10 / 14 / 98$ & $1.7 \pm 0.6$ & $30 \pm 2$ \\
\hline & $10 / 21 / 98$ & $0.7 \pm 0.4$ & $12 \pm 1$ \\
\hline & $10 / 28 / 98$ & $1.7 \pm 0.6$ & $43 \pm 2$ \\
\hline & $11 / 04 / 98$ & $1.6 \pm 0.5$ & $16 \pm 2$ \\
\hline & $11 / 11 / 98$ & $0.9 \pm 0.8$ & $15 \pm 2$ \\
\hline & $11 / 18 / 98$ & $0.8 \pm 0.4$ & $24 \pm 2$ \\
\hline & $11 / 24 / 98$ & $0.6 \pm 0.5$ & $16 \pm 2$ \\
\hline & $12 / 02 / 98$ & $0.7 \pm 0.4$ & $13 \pm 1$ \\
\hline & $12 / 09 / 98$ & $0.3 \pm 0.4$ & $11 \pm 1$ \\
\hline & $12 / 16 / 98$ & $0.9 \pm 0.4$ & $13 \pm 1$ \\
\hline & $12 / 23 / 98$ & $1.0 \pm 0.5$ & $26 \pm 2$ \\
\hline & $12 / 30 / 98$ & $0.4 \pm 0.4$ & $27 \pm 2$ \\
\hline \multirow[t]{13}{*}{ Monteview } & $10 / 07 / 98$ & $1.9 \pm 0.9$ & $27 \pm 3$ \\
\hline & $10 / 14 / 98$ & $1.3 \pm 0.6$ & $30 \pm 2$ \\
\hline & $10 / 21 / 98$ & $2.4 \pm 0.7$ & $20 \pm 2$ \\
\hline & $10 / 28 / 98$ & $1.7 \pm 1.3$ & $30 \pm 5$ \\
\hline & $11 / 04 / 98$ & $2.0 \pm 0.6$ & $32 \pm 2$ \\
\hline & $11 / 11 / 98$ & $1.5 \pm 1.0$ & $18 \pm 2$ \\
\hline & $11 / 18 / 98$ & $1.5 \pm 0.6$ & $41 \pm 2$ \\
\hline & $11 / 24 / 98$ & $0.5 \pm 0.5$ & $18 \pm 2$ \\
\hline & $12 / 02 / 98$ & $0.8 \pm 0.4$ & $20 \pm 2$ \\
\hline & $12 / 09 / 98$ & $0.4 \pm 0.4$ & $11 \pm 1$ \\
\hline & $12 / 16 / 98$ & $1.1 \pm 0.5$ & $31 \pm 2$ \\
\hline & $12 / 23 / 98$ & $1.2 \pm 0.6$ & $36 \pm 2$ \\
\hline & $12 / 30 / 98$ & $1.8 \pm 0.6$ & $38 \pm 2$ \\
\hline Mud & $10 / 07 / 98$ & $1.7 \pm 0.6$ & $21 \pm 2$ \\
\hline \multirow[t]{8}{*}{ Lake } & $10 / 14 / 98$ & $2.0 \pm 0.6$ & $29 \pm 2$ \\
\hline & $10 / 21 / 98$ & $2.2 \pm 0.6$ & $22 \pm 2$ \\
\hline & $10 / 28 / 98$ & $0.9 \pm 1.1$ & $33 \pm 5$ \\
\hline & $11 / 04 / 98$ & $2.3 \pm 0.6$ & $34 \pm 2$ \\
\hline & $11 / 11 / 98$ & $1.5 \pm 0.9$ & $19 \pm 2$ \\
\hline & $11 / 18 / 98$ & $1.2 \pm 0.6$ & $48 \pm 3$ \\
\hline & $11 / 24 / 98$ & $1.0 \pm 0.6$ & $16 \pm 2$ \\
\hline & $12 / 02 / 98$ & $1.3 \pm 0.5$ & $20 \pm 2$ \\
\hline
\end{tabular}




\section{Appendix C \\ Weekly Gross Alpha and Gross Beta Concentrations in Air $4^{\text {th }}$ Quarter 1998}

Gross Alpha Concentration $\pm 2 \mathrm{~s}$

Gross Beta Concentration $\pm 2 s$

Location Collection Date

$\left(\mu \mathrm{Ci} / \mathrm{ml} \mathrm{x} \mathrm{10^{-15 } )}\right.$

$\left(\mu \mathrm{Ci} / \mathrm{ml} \times 10^{-15}\right)$

\begin{tabular}{|c|c|c|c|}
\hline \multirow{4}{*}{$\begin{array}{l}\text { Mud Lake } \\
\text { (cont.) }\end{array}$} & $12 / 09 / 98$ & $0.4 \pm 0.4$ & $15 \pm 2$ \\
\hline & $12 / 16 / 98$ & $1.0 \pm 0.5$ & $38 \pm 2$ \\
\hline & $12 / 23 / 98$ & $1.4 \pm 0.6$ & $37 \pm 2$ \\
\hline & $12 / 30 / 98$ & $1.5 \pm 0.6$ & $46 \pm 2$ \\
\hline Reno & $10 / 07 / 98$ & $1.5 \pm 0.6$ & $20 \pm 2$ \\
\hline \multirow[t]{12}{*}{ Ranch } & $10 / 14 / 98$ & $2.1 \pm 0.7$ & $31 \pm 2$ \\
\hline & $10 / 21 / 98$ & $1.3 \pm 0.6$ & $16 \pm 2$ \\
\hline & $10 / 28 / 98$ & $2.3 \pm 0.8$ & $45 \pm 3$ \\
\hline & $11 / 04 / 98$ & $1.1 \pm 0.5$ & $23 \pm 2$ \\
\hline & $11 / 11 / 98$ & $1.7 \pm 1.1$ & $18 \pm 2$ \\
\hline & $11 / 18 / 98$ & $1.2 \pm 0.6$ & $33 \pm 2$ \\
\hline & $11 / 24 / 98$ & $0.6 \pm 0.6$ & $18 \pm 2$ \\
\hline & $12 / 02 / 98$ & $1.0 \pm 0.5$ & $17 \pm 2$ \\
\hline & $12 / 09 / 98$ & $0.1 \pm 0.4$ & $11 \pm 2$ \\
\hline & $12 / 16 / 98$ & $0.4 \pm 0.4$ & $21 \pm 2$ \\
\hline & $12 / 23 / 98$ & $1.0 \pm 0.6$ & $35 \pm 2$ \\
\hline & $12 / 30 / 98$ & $0.8 \pm 0.5$ & $32 \pm 2$ \\
\hline Reno & $10 / 07 / 98$ & $1.0 \pm 0.5$ & $19 \pm 2$ \\
\hline Ranch & $10 / 14 / 98$ & $1.4 \pm 0.6$ & $29 \pm 2$ \\
\hline \multirow[t]{11}{*}{ Replicate } & $10 / 21 / 98$ & $1.3 \pm 0.5$ & $17 \pm 2$ \\
\hline & $10 / 28 / 98$ & $2.2 \pm 0.7$ & $39 \pm 2$ \\
\hline & $11 / 04 / 98$ & $2.0 \pm 0.6$ & $31 \pm 2$ \\
\hline & $11 / 11 / 98$ & $1.4 \pm 0.9$ & $17 \pm 2$ \\
\hline & $11 / 18 / 98$ & $1.0 \pm 0.5$ & $34 \pm 2$ \\
\hline & $11 / 24 / 98$ & $0.6 \pm 0.5$ & $15 \pm 2$ \\
\hline & $12 / 02 / 98$ & $1.0 \pm 0.5$ & $17 \pm 2$ \\
\hline & $12 / 09 / 98$ & $0.2 \pm 0.4$ & $9 \pm 1$ \\
\hline & $12 / 16 / 98$ & $0.7 \pm 0.4$ & $26 \pm 2$ \\
\hline & $12 / 23 / 98$ & $0.8 \pm 0.5$ & $32 \pm 2$ \\
\hline & $12 / 30 / 98$ & $0.8 \pm 0.5$ & $34 \pm 2$ \\
\hline INEEL & $10 / 07 / 98$ & $1.4 \pm 0.5$ & $21 \pm 2$ \\
\hline Main & $10 / 14 / 98$ & $1.9 \pm 0.6$ & $29 \pm 2$ \\
\hline \multirow[t]{6}{*}{ Gate } & $10 / 21 / 98$ & $1.2 \pm 0.4$ & $19 \pm 2$ \\
\hline & $10 / 28 / 98$ & $2.5 \pm 0.7$ & $44 \pm 3$ \\
\hline & $11 / 04 / 98$ & $2.6 \pm 0.7$ & $36 \pm 2$ \\
\hline & $11 / 11 / 98$ & $2.5 \pm 1.0$ & $19 \pm 2$ \\
\hline & $11 / 18 / 98$ & $0.9 \pm 0.5$ & $39 \pm 2$ \\
\hline & $11 / 24 / 98$ & $0.3 \pm 0.4$ & $19 \pm 2$ \\
\hline
\end{tabular}




\section{Appendix C \\ Weekly Gross Alpha and Gross Beta Concentrations in Air $4^{\text {th }}$ Quarter 1998}

\begin{tabular}{|c|c|c|c|}
\hline Location & Collection Date & $\begin{array}{l}\text { Gross Alpha Concentration } \pm 2 \mathrm{~s} \\
\left(\mu \mathrm{Ci} / \mathrm{ml} \times 10^{-15}\right)\end{array}$ & $\begin{array}{r}\text { Gross Beta Conc } \\
(\mu \mathrm{Ci} / \mathrm{ml} \mathrm{x}\end{array}$ \\
\hline INEEL & $12 / 02 / 98$ & $0.9 \pm 0.4$ & $21 \pm 2$ \\
\hline Main & $12 / 09 / 98$ & $0.4 \pm 0.4$ & $13 \pm 1$ \\
\hline Gate & $12 / 16 / 98$ & $1.1 \pm 0.5$ & $30 \pm 2$ \\
\hline \multirow[t]{2}{*}{ (cont.) } & $12 / 23 / 98$ & $0.9 \pm 0.5$ & $38 \pm 2$ \\
\hline & $12 / 30 / 98$ & $1.2 \pm 0.5$ & $43 \pm 2$ \\
\hline \multirow[t]{13}{*}{ EFS } & $10 / 07 / 98$ & $1.2 \pm 0.5$ & $20 \pm 2$ \\
\hline & $10 / 14 / 98$ & $2.5 \pm 0.7$ & $32 \pm 2$ \\
\hline & $10 / 21 / 98$ & $1.3 \pm 0.5$ & $19 \pm 2$ \\
\hline & $10 / 28 / 98$ & $1.8 \pm 0.6$ & $48 \pm 3$ \\
\hline & $11 / 04 / 98$ & $2.2 \pm 0.7$ & $34 \pm 2$ \\
\hline & $11 / 11 / 98$ & $2.0 \pm 1.0$ & $21 \pm 2$ \\
\hline & $11 / 18 / 98$ & $1.0 \pm 0.5$ & $45 \pm 2$ \\
\hline & $11 / 24 / 98$ & $0.6 \pm 0.5$ & $16 \pm 2$ \\
\hline & $12 / 02 / 98$ & $1.0 \pm 0.4$ & $21 \pm 2$ \\
\hline & $12 / 09 / 98$ & $0.1 \pm 0.3$ & $14 \pm 1$ \\
\hline & $12 / 16 / 98$ & $0.7 \pm 0.4$ & $31 \pm 2$ \\
\hline & $12 / 23 / 98$ & $1.3 \pm 0.6$ & $25 \pm 2$ \\
\hline & $12 / 30 / 98$ & $1.0 \pm 0.5$ & $42 \pm 2$ \\
\hline Van Buren & $10 / 07 / 98$ & $0.7 \pm 0.3$ & $13 \pm 1$ \\
\hline \multirow[t]{12}{*}{ Avenue } & $10 / 14 / 98$ & $2.4 \pm 0.6$ & $31 \pm 2$ \\
\hline & $10 / 21 / 98$ & $1.1 \pm 0.5$ & $19 \pm 2$ \\
\hline & $10 / 28 / 98$ & $2.3 \pm 0.6$ & $45 \pm 2$ \\
\hline & $11 / 04 / 98$ & $1.8 \pm 0.6$ & $30 \pm 2$ \\
\hline & $11 / 11 / 98$ & $0.9 \pm 0.8$ & $20 \pm 2$ \\
\hline & $11 / 18 / 98$ & $1.2 \pm 0.5$ & $38 \pm 2$ \\
\hline & $11 / 24 / 98$ & $0.6 \pm 0.4$ & $17 \pm 2$ \\
\hline & $12 / 02 / 98$ & $0.3 \pm 0.3$ & $21 \pm 2$ \\
\hline & $12 / 09 / 98$ & $-0.1 \pm 0.3$ & $12 \pm 1$ \\
\hline & $12 / 16 / 98$ & $0.9 \pm 0.5$ & $29 \pm 2$ \\
\hline & $12 / 23 / 98$ & $1.2 \pm 0.5$ & $35 \pm 2$ \\
\hline & $12 / 30 / 98$ & $-0.4 \pm 0.2$ & $34 \pm 2$ \\
\hline
\end{tabular}

